\title{
Beyond the State: New Zealand's State houses from modest to modern by Bill Mackay and Andrea Stevens
}

\author{
Michael Austin
}

The New Zealand State house is a strange mythological beast. Some of the myths are that the 1935 First Labour Government wanted it to be 'as good a house as those bastards in Remuera', and consequently it was to be a well-built cottage (English origins are usually assumed for the designs, but Peter Middleton believed they were based on Cape Cod cottages). The Auckland University Labour Club criticized the decision as out of touch with international architecture. Modernist blocks were built from 1940, but they were regarded as unpopular with families, who wanted each house to be distinguishable from its neighbours. Opponents claimed this was so that drunk workers returning from the 'six o'clock swill' could recognize which house was theirs.

The latest book on the State house doesn't indulge in these myths, but concentrates instead on the architecture of the houses, for which it has only appreciation and praise. The book is in two parts: the first is by Bill Mackay and is arranged chronologically; not quite a history of the house that we think we know, but exposing eclectic variations and a little known prehistory. Particularly the sections on the Petone Housing, and another one discussing the little known Railway Housing, make for interesting reading.

The second part, by Andrea Stevens, illustrates a selection of the original State houses with their current occupants - academics, artists and professionals. Not the working class, and not those who are currently 'allocated' State houses and who, according to contemporary myths, are without work. The text in section, which has no conclusion, is followed by the plans of the houses, both original and altered, in an appendix of sorts. This arrangement is awkward for readers who have to shuffle back and forth to see what was done with the original architectural designs.

However, the book is not aimed at architects but at a wider readership, almost a coffee table publication for those of us who read home making magazines. Many captions accompanying the images photographed by Simon Devitt seem to be struggling to find something to say, perhaps a consequence of an absence of argument or theme in the work as a whole. Frequently, there are photos of books in piles or in bookcases, providing clues about the current inhabitant's tastes, and the book meticulously acknowledges every painting and art piece. The women are still shown in the kitchen, but they are now accompanied by partners and children.

The huge respect with which the original houses have been treated is quite extraordinary. Where additions have been made, they keep the original house intact, in one way or another. Common is the addition of outside living areas, which were lacking in the originals. All examples in this book show the current occupants' affection of for their houses, as well as the varied ways in which people use them. What a contrast with architects' attitudes to State houses half a century ago, when they were considered beneath contempt. No architect in the sixties could have been persuaded that State houses had "wonderful proportions and gentle human scale" (105).

Interestingly, it is difficult to discern what the criticism of State houses aims at. In other words, criticising the houses is an implicit criticism of their occupants. A common criticism over the decades has been the lack of variety. However, there have actually been many innovative State house designs in the half century since the early cottages, some of which even made it into architectural magazines, but the book explores neither these nor how current State houses are occupied. 
The State houses in this book are owned and occupied by Pākehā, in contrast with the present day occupants of State rental houses. The book has a section discussing Māori Housing, but the situation is more complex. Houses for Māori were among the first goals mooted by the first Labour Government, and they were 'pepper-potted' in Pākehā suburbs. The Māori Affairs programme envisaged that the occupants would purchase the houses, but Māori (and Pacific Islanders) applied instead for State rental houses. As a result, State house suburbs, such as Ōtara and Porirua, are predominantly occupied by a Polynesian population.

This book has a chatty style, addressing the reader directly with the use of 'we' and 'our'. And it cheerfully discusses 'style', an issue modernism was supposed to eliminate. Generally, this book leaves the reader wanting to know more, with its gentle discussions and abrupt endings.

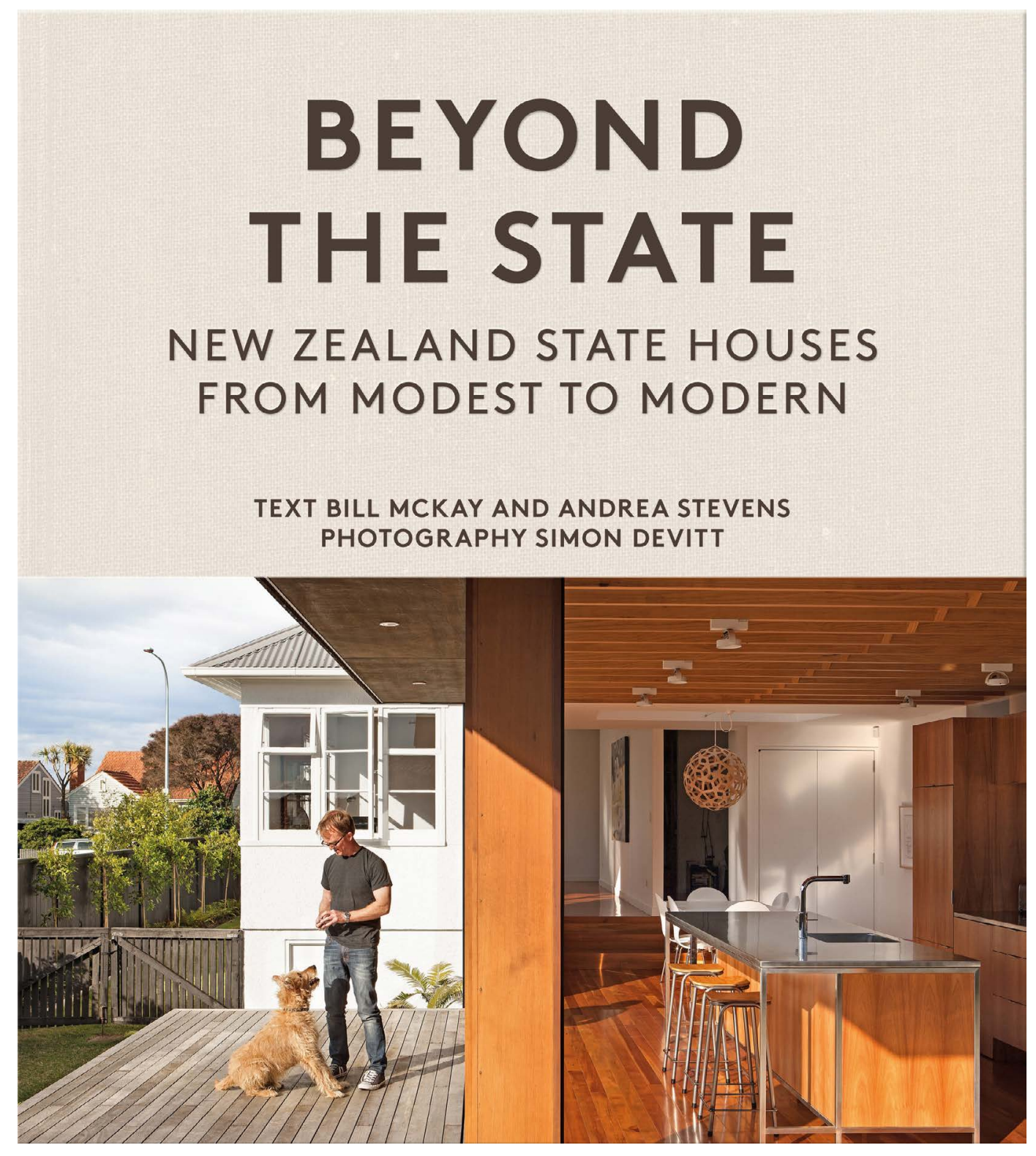

Photography: Simon Devitt

Penguin: Auckland, New Zealand, 2014. 